\title{
Studies on the Dopamine-evoked Parotid Saliva in the Rabbit
}

\author{
by \\ Hajime MURAKAMI,* Hiroshi SUGIYA,* Shunzo KAKISHITA,* \\ Susumu Ooyama* and Toshinori ISHIKAWA**
}

\section{Introduction}

Dopamine(3,4-dihydroxyphenyl ethylamine) is found in high concentration in many mammalian tissues [1, 2]. Dopamine has been considered the biochemical precursor of noradrenaline though [3]. At present, it has been recognized that dopamine is the third physiological active catecholamine ranked next to noradrenaline and adrenaline [4]. In several dopamine-induced actions, it is investigated that there is the dopamine action on alpha-adrenergic receptors and on beta-adrenergic receptors [5-13]. In addition, the concept of specific dopamine receptor was strengthened by the discovery of specific dopamine receptor blocking agent [14-16]. FURUTA et al. [17] have reported that L-DOPA and dopamine increase the secretion of pancreatic juice and suggested that there is a specific dopamine receptor in the dog pancreas. In the previous report [18], from the results investigated by the method of flux chamber, we have suggested that a specific dopamine receptor is present in the tegumental membrane of the rat and rabbit submaxillary glands. In the present investigation, we have examined how dopamine acts on the secretion of parotid saliva in the rabbit and also designed to clarify the mechanism of dopamine action on the evoking secretion of parotid saliva.

\section{Materials and Methods}

Rabbits of either sex (body weight about 2.3 to $2.5 \mathrm{~kg}$ ) were used in this experiment.

A polyethylene tube with a diameter of $1 \mathrm{~mm}$ was inserted into the parotid duct and secreting volume of parotid saliva was measured by a drop counter (Ugo Basil Photoelectric Drop-Counter) and the secretory rate expressed as secreting volume $(\mathrm{ml}) / \mathrm{min}$. . The drugs were as follows: Dopamine hydrochloride (Sigma), Priscol (Ciba), Propranolol hydrochloride (Sigma), Chlorpromazine (Shionogi) and haloperidol (Dainihon). Each drug was dissolved in $1.0 \mathrm{ml}$ of distilled water and intravenously injected into animals. Drugs, as a blocking agent were intravenously injected $3 \mathrm{~min}$ before the injection of dopamine.

* 村上 元, 杉谷博士, 柿下俊三, 大山 進：Department of Physiology Nihon University School of Dentistry at Matsudo, Matsudo, Chiba, Japan.

** 石川稔矩: Department of Biology, Nihon University School of Dentistry at Matsudo, Matsudo Chiba, Japan. 


\section{Results}

3.1 Dose-dependent response of dopamine to the secretion of parotid saliva.

The secretion of parotid saliva was gradually evoked by intravenous administration of dopamine in various doses (dopamine dose: $5 \mathrm{mg} / \mathrm{kg}, 10 \mathrm{mg} / \mathrm{kg}, 20 \mathrm{mg} / \mathrm{kg}$, $30 \mathrm{mg} / \mathrm{kg}, 100 \mathrm{mg} / \mathrm{kg}$ ), as shown in Fig. 1. The peak of secretory rate appeared $3 \mathrm{~min}$. after the injection of dopamine in almost all experiments. In addition, these responses were dose-dependent. These results were summarized as the dose-response curve, as shown in Fig. 2.

\subsection{Influence of priscol on the dopamine-evoked parotid saliva.}

In the pretreatment of priscol, the dopamine-evoked parotid saliva was not inhibited by rising the dose of priscol $(5 \mathrm{mg} / \mathrm{kg}, 10 \mathrm{mg} / \mathrm{kg}, 20 \mathrm{mg} / \mathrm{kg})$ as shown in Fig. 3.

\subsection{Influence of propranolol on the dopamine-evoked parotid saliva.}

In the pretreatment of propranolol, the dopamine-evoked parotid saliva was not inhibited by rising the dose of propranolol $(0.5 \mathrm{mg} / \mathrm{kg}, 1 \mathrm{mg} / \mathrm{kg}, 2 \mathrm{mg} / \mathrm{kg})$, as shown in Fig. 4.

\subsection{Antagonistic effect of chlorpromazine on the dopamine-evoked parotid saliva.}

In the pretreatment of chlorpromazine $0.25 \mathrm{mg} / \mathrm{kg}$, the dopamine-evoked parotid saliva was inhibited and in the pretreatment of $0.5 \mathrm{mg} / \mathrm{kg}$, dopamine-evoked parotid saliva was nearly blocked in the secretory rate, as shown in Fig. 5.

\subsection{Antagonistic effect of haloperidol on the dopamine-evoked parotid saliva.}

In the pretreatment of haloperidol $1 \mathrm{mg} / \mathrm{kg}$, the dopamine-evoked parotid saliva was inhibited and in the pretreatment of haloperidol $2 \mathrm{mg} / \mathrm{kg}$, the dopamine-evoked parotid saliva was nearly blocked in the secretory rate, as shown in Fig. 6.

\section{Discussion}

In the present study, we demonstrated that dopamine-evoked salivary secretion with a certain duration from the rabbit parotid gland and its response was dosedependent in the secretory rate. The response seemed to be similar to the responses induced by the other sympathomimetic amines (e.g. noradrenaline, adrenaline or isoproterenol) in rabbit parotid gland $[19,20]$. In the predominant effects of dopamine on several tissues or organs, there are the actions on alpha-adrenergic receptors, on beta-adrenergic receptors and on specific dopamine receptors [5-18]. In the present experiment, in the pretreatment of priscol, alpha-adrenergic blocking agent, dopamineevoked parotid saliva was not inhibited. The result indicates that the dopamine effect on the parotid gland was not induced via alpha-adrenergic receptor. In the pretreatment of propranolol, beta-adrenergic blocking agent, dopamine-evoked parotid saliva was not inhibited, either. The result indicates that the dopamine effect on the gland was not induced via beta-adrenergic receptor. Neuroleptic drugs, chlorpromazine 


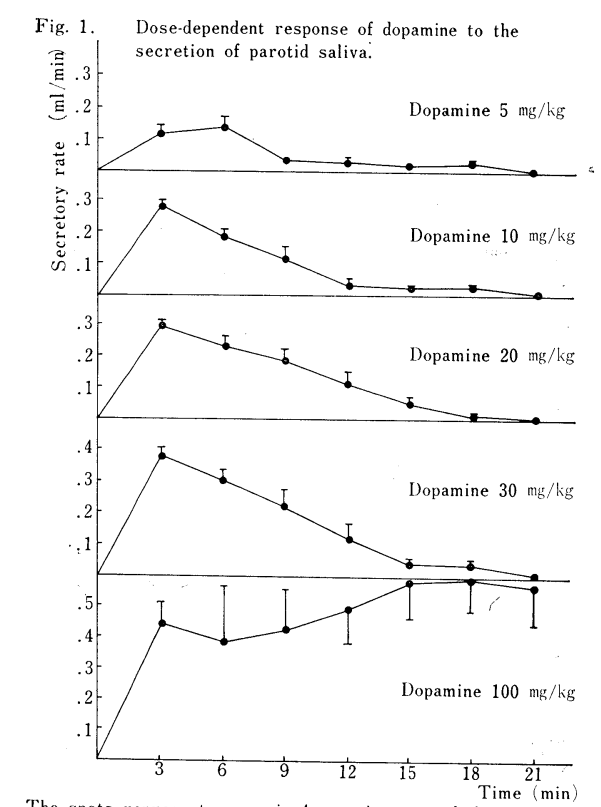

The spots represent means in 4 experiments and the vertical bars indicate the standard error of means.

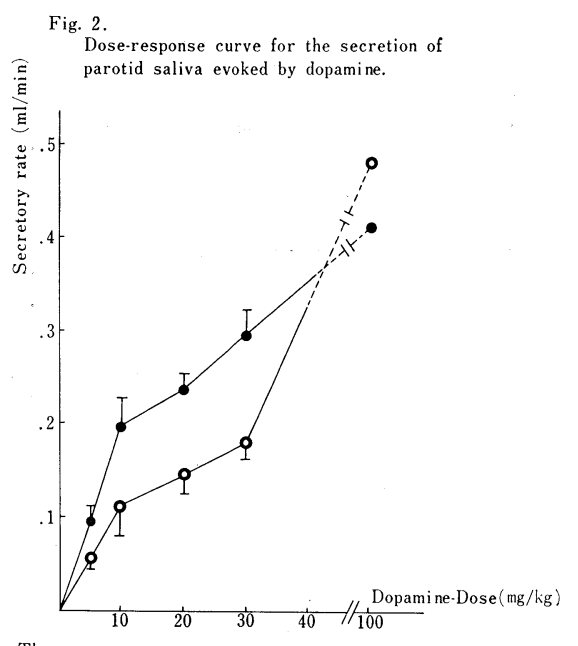

The spots represent means in 4 experiments and the

- : Secretory rate of the secreting volume for $9 \mathrm{~min}$.

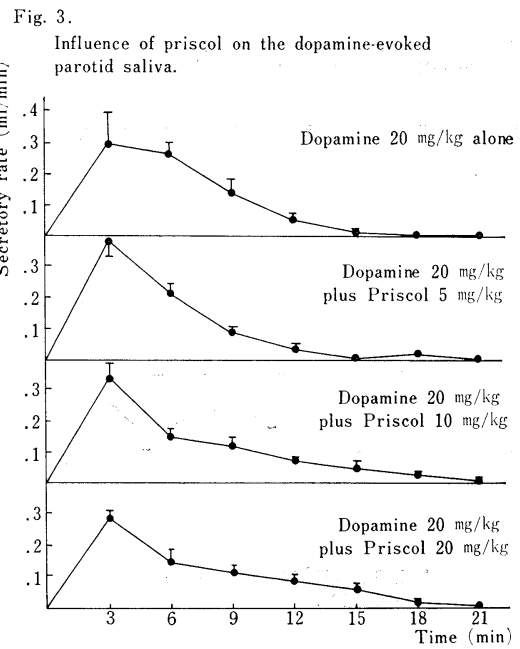

The spots represent means in 4 experiments and vertical bars indicate the standared error of means. 

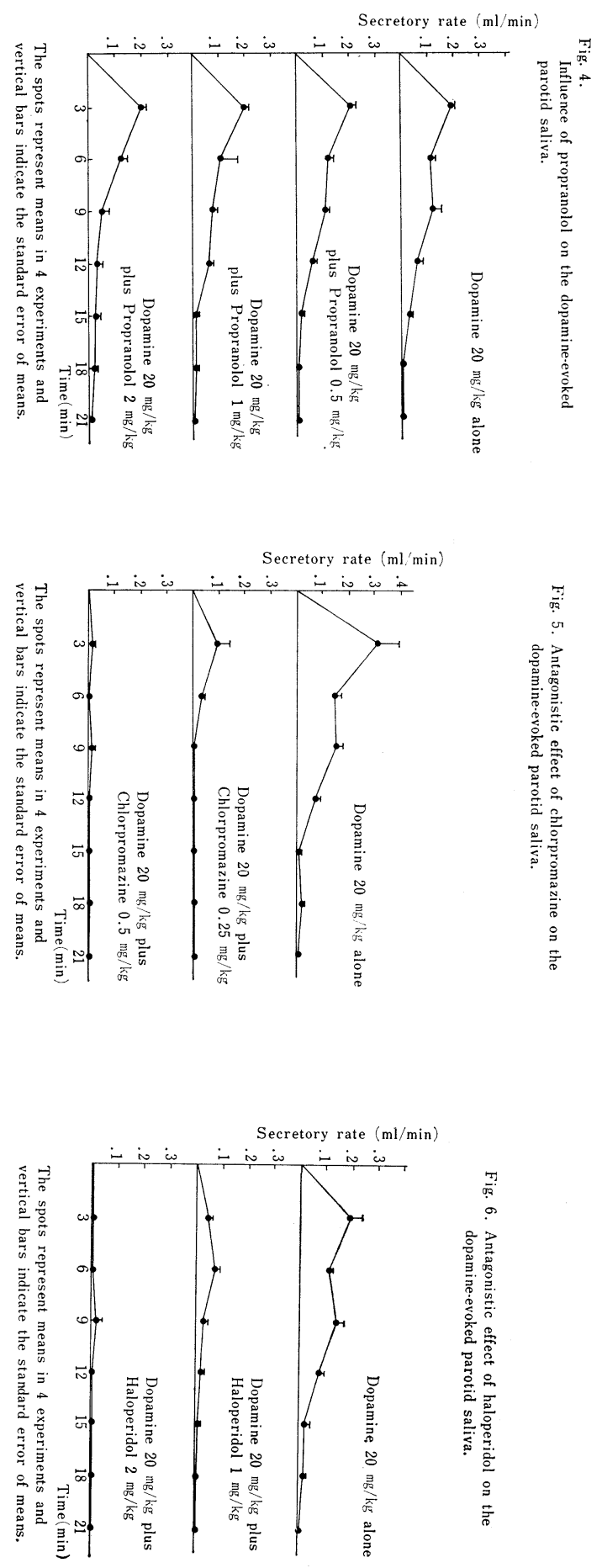
and haloperidol are well known as a potent dopamine receptor blocking agent [1416]. In the pretreatment of chlorpromazine $0.25 \mathrm{mg} / \mathrm{kg}$, dopamine-evoked parotid saliva was markedly inhibited. In addition, in a high dose of chlorpromazine $(0.5$ $\mathrm{mg} / \mathrm{kg}$ ), dopamine-evoked parotid saliva was nearly blocked. In the pretreatment of haloperidol $1 \mathrm{mg} / \mathrm{kg}$, dopamine-evoked parotid saliva was markedly inhibited. In a high dose of haloperidol $(2 \mathrm{mg} / \mathrm{kg}$ ), dopamine-evoked parotid saliva was nearly blocked. These results indicate that dopamine-evoked parotid saliva may be produced by stimulating the dopamine receptor in the gland. Furthermore, the results suggest that the specific dopamine receptor may be present in the rabbit parotid gland as suggested by Furuta et al. [17] in the dog pancreas. However, whether dopamine induced its response directly or indirectly could not be firmly established by such an experimental method. It has been reported that various mammalian tissues contain adenylate cyclase systems associated with dopamine receptors [21-23]. In retina, developmental and localizating studies are indicative of the fact that an involvement of dopamine stimulated adenylate cyclase in neuronal function [24]. From the above mentioned reports, naturally, much further study is needed to demonstrate clearly a relationship between changes of cyclic nucleotide (e.g. cyclic-AMP and cyclic-GMP) and process of salivary secretion evoked by dopamine.

\section{Summary}

It was demonstrated that the secretion of parotid saliva is evoked by the administration of dopamine into the rabbit. The response was dose-dependent in the secretory rate. In addition, the dopamine-evoked parotid saliva was not inhibited by rising the dose of priscol or propranolol. Whereas, the dopamine-evoked parotid saliva was nearly blocked by chlorpromazine or haloperidol. From the above mentioned results, we suggested that the specific dopamine receptor may be present in the rabbit parotid gland.

\section{References}

[1] Hagen, P.: The storage and release of catecholamines; Pharmacol. Rev., 11, 361-373, (1959).

[2] Schumann, H. J. and Heller, I.: Hydroxytyramine content of organs; Arch. exp. Path. Pharmak., 236. 474-482, (1959).

[3] Blaschko, H.: The development of current concepts of catecholamine formation; Pharmacol. Rev., 11, 307-316, (1959).

[4] Hornykiewicz, O.: Dopamine(3-hydroxytyramine) and brain function; Pharmacol. Rev., 18, 925-964, (1966).

[5] Rossum van, J. M.: The significance of dopamine-receptor blockade for mechanism of action of neuroleptic drugs; Arch. Int. Pharmacodyn. Ther., 160, 492-494, (1900).

[6] Allwood, M. J., Cobbold, A. F. and Ginsburg, J.: Peripheral vascular effects of noradrenaline isopropyl noradrenaline and dopamine; Brit. Med. Bull., 19, 132-136, (1963).

[7] Dietzel, W., Massion, W. H. and Hinshaw, L. B.: Dopamine-induced changes in isogravimetric cappillary pressure and arterial and venous resistances; Arzneim-forsh., 20, 513-515, (1970).

[8] Eble, J. N.: A proposed mechanism for the depressor effect of dopamine in the anesthetized dog; J. Pharmacol. Exp. Ther., 145, 64-70, (1964). 
[9] McNay, J. L., McDonald, R. H. JR. and GoldberG, L. I.: Direct renal vasodilation produced by dopamine in the dog; Circ. Res., 16, 510-517, (1965).

[10] McDonald, R. H. JR. and Goldberg, L. I.: Analysis of the cardiovascular effects of dopamine in the dog; J. Pharmacol. Exp. Ther., 140, 60-66, (1963).

[11] Allwood, M. J. and Ginsburg, J.: Peripheral vascular and other effects of dopamine infusions in man; Clin. Sci. (London), 27, 271-281, (1964).

[12] Gatagounis. J.: Structural activity relationships of a series of amines injected before and after monoamine oxidase inhibitor; Arch. Int. Pharmacodyn Ther., 154, 412-420, (1965).

[13] Black, W. L. and Rolett, E. L.: Cardiovascular adrenergic activity of dopamine in the dog, Amer. Heart J., 75, 233-239, (1968).

[14] Yeh, B. K., McNay, J. L. and Goldberg, L. I.: Attenuation of dopamine renal and mesenteric vasodilation by haloperidol: Evidence for a specific receptor; J. Pharmacol. Exp. Thre., 168, 303-309, (1969).

[15] Brotzu, G.: Inhibition by chlorpromazine of effects of dopamine on the dog kidney; Pharm. Pharmacol., 22, 664-667, (1970).

[16] Goldberg, L. I. and YeH, B. K.: Attenuation of dopamine-induced renal vasodilation in the dog by phenothiazines; European J. Pharmacol. 15, 36-40, (1971).

[17] Furuta, Y., Hashimoto, K., Iwatsuki, K. and Takeuchi, O.: Effects of enzyme inhititors of catecholamine metabolism and of haloperidol on pancreatic secretion induced by L-DOPA and by dopamine in dogs; Brit, J. Pharmac., 47, 77-84, (1973).

[18] Murakami, H., Kakishita, S., Watanabe, H. and Sano, A.: Studies on the local membrane response potential induced by dopamine in the isolated tegumental membrane of the rat submaxillary gland; J. Nihon Univ. Sch. Dent., in press.

[19] Tanaka, H., Suhara, R., Murakami, H. et al.: Influence of cyclic-AMP on the adrenalineevoked parotid saliva in the rabbit; J. Physiol. Soc. Japan, 34, 576-577, (1972).

[20] Ooyama, S., Suhara, R., Murakami, H. et al.: Influences of alpha-adrenergic blocker and betaadrenergic blocker on the adrenaline-evoked parotid saliva in the rabbit, In abstract, Congress of Nihon University, 1972, p. 25.

[21] Kebabian, J. W., Petzold, G. L. and Greengard, P.: Dopamine-sensitive adenylate cyclase in caudate nucleus of rat brain and its similarity to the dopamine receptor; Proc. Natl. Acad. Sci. USA 69, 2145-2149, (1972).

[22] Kebabian, J. W., Clement-Cormier, Y. C., Petzold, G L. and Greengard, P.: Chemistry of Dopamine Receptors; Advance in Neurology 9, pp. 1-11, Raven Press, New York, (1975).

[23] Makman, M. H., Mishra, R. K. and Brown, J. H.: Drug interactions with dopaminestimulated adenylate cyclases of caudate nucleus and retina: Direct agonist effect of a piribedil metabolite; Advance in Neurology 9, pp. 213-222, Raven Press, New York, (1975).

[24] Brown, J. H., Makman, M. H. and Opler, L. A.: Development and localization of dopaminesensitive adenylate cyclase of mammalian retina; Fed. Proc. 32, 679, (1973). 